\title{
ANALISIS FINANSIAL DAN STRATEGI PENGEMBANGAN USAHA MIKRO, KECIL DAN MENENGAH AMPLANG MENUJUONE VILLAGE ONE PRODUCT
}

\author{
FINANCIAL ANALYSIS AND ADMINISTRATION OF MICRO, SMALL AND MEDIUM \\ BUSINESS STRATEGIES AMPLANGING TO ONE PRODUCT VILLAGE
}

\author{
I.Cholid1a, A.P.Wardhanu1, Martanto1
}

1Jurusan Pengelolaan Hasil Pertanian Politeknik Negeri Ketapang, Jl. Rangga Sentap, 78813

aKorespondensi: Irfan Cholid. Telepon; email : yeobo.irfan@gmail.com

(Diterima: 04-12-2019; Ditelaah: 06-12-2019; Disetujui: 28-09-2020)

\begin{abstract}
The Micro, Small and Medium Enterprises (MSME) sector in Indonesia has some important roles in development, one of which is MSMEs are able to reduce unemployment due to labor force that is not absorbed in the world of work. One of the village development efforts is through One Village One Product approach. Kauman Village is the center of amplang MSME which is considered by the community to be a typical product of the area and has been operating for years and still exists up to today. Despite being operated for a while, its financial feasibility has not been recognized. In addition, business development strategies are also essential because until now most of these MSMEs still face challenges which one of them is on the marketing aspect. The marketing strategy used is conventional one, which is considered less suitable for today's digital era. The analytical method used to determine the financial condition ofamplang's business in KaumanVillage,Ketapang is by calculating the net profit of the business. While the SWOT analysis is used to formulate the amplang MSME development strategy in Kauman Village based on the respondents' answers on the questionnaires. Based on the results of the financial analysis with net profit calculation, it can be concluded that all amplang MSMEs are feasible to maintain. Meanwhile, according to the results of the SWOT analysis, all amplang MSMEs are positive and in quadrant I which proves that amplangMSMEs are very strong and have a chance to grow and develop.
\end{abstract}

Keywords: UMKM, amplang, financial, SWOT, OVOP.

\section{ABSTRAK}

Sektor Usaha Mikro Kecil dan Menengah (UMKM) di Indonesia memiliki peran penting dalam pembangunan, salah satunya adalah UMKM mampu mengurangi pengangguran akibat angkatan kerja yang tidak terserap dalam dunia kerja. Salah satu upaya pengembangan desa adalah melalui pendekatan One Village One Product atau Satu Desa Satu Produk. Kelurahan Kauman merupakanlokasi sentral UMKM Amplang yang dianggap masyarakat menjadi produk khas dari daerah tersebut dan sudah berlangsung selama bertahun-tahun dan masih bertahan sampai saat ini. Meskipun usaha tersebut telah berjalan cukup lama, kelayakan finansial dari kegiatan usaha tersebut belum diketahui. Selain itu, juga perlu dilakukan strategi pengembangan usaha, karena sampai saat ini sebagian besar UMKM tersebut masih memiliki beberapa kendala, salah satunya adalah pada aspek pemasaran. Strategi pemasaran yang dilakukan masih menggunakan metode konvensional, dimana metode ini dianggap sudah kurang sesuai pada era digital seperti saat ini. Metode analisis yang digunakan untuk mengetahui kondisi finansial usaha Amplang di Kelurahan Kauman Kabupaten Ketapang adalah dengan perhitungan laba bersih usaha. Sedangkan analisis SWOT digunakan untuk merumuskan strategi pengembangan UMKM Amplang di Kelurahan Kauman berdasarkan hasil pengisian kuesioner yang diberikan kepada responden. Berdasarkan hasil analisis finansial dengan perhitungan laba bersih dapat disimpulkan bahwa seluruh UMKM Amplang layak untuk terus dilakukan. Sedangkan menurut hasil analisis SWOT, seluruh UMKM Amplang benilai positif dan berada di kuadran I yang membuktikan UMKM Amplang sangat kuat dan berpeluang.

Kata kunci: Amplang, UMKM, Finansial, SWOT, OVOP. 
Cholid. I., Wardhanu. A. P., \& Martanto. (2020). Analisis Finansial Dan Strategi Pengembangan Usaha Mikro, Kecil dan Menengah Amplang Menuju One Village one Produck . Jurnal Pertanian, 11(2); 72-80.

\section{PENDAHULUAN}

Sektor Usaha Mikro Kecil dan Menengah (UMKM) di Indonesia memiliki peran penting dalam pembangunan, salah satunya adalah UMKM mampu mengurangi pengangguran akibat angkatan kerja yang tidak terserap dalam dunia kerja. Selain itu dalam pengembangan sektor UMKM dengan mensinergikannya dengan industri besar melalui pola kemitraan, juga akan memperkuat struktur ekonomi baik nasional maupun daerah (Raliby dan Rusdjijati, 2016).

Salah satu upaya pengembangan desa adalah melalui pendekatan One Village One Product atau Satu Desa Satu Produk. Pendekatan One Village One Product (OVOP) pertama kali diinisiasi di Oita, Jepang, OVOP merupakan suatu pendekatan pengembangan potensi daerah di satu wilayah untuk menghasilkan produk yang mampu bersaing di pasar global, dengan tetap memiliki ciri khas keunikan karakteristik dari daerah tersebut (Triharini et. al., 2014).

Di Indonesia, program OVOP merupakan kegiatan yang dilaksanakan oleh Kementerian Koperasi dan Usaha Kecil dan Menengah Republik Indonesia yang pelaksanaannya didasari pada Inpres No. 6 Tahun 2007 Tentang Percepatan Sektor Riil dan Pembangunan Usaha Mikro Kecil dan Menengah tanggal 8 Juni 2007 yang mengamanatkan pengembangan sentra melalui pendekatan OVOP. Pendekatan OVOP telah diterapkan terlebih dulu di negaranegara Asia sejak tahun 2006. Beberapa negara Asia yang sudah menerapkan OVOP diantaranya adalahFilipina (One Town One Product), Thailand (One Tambon One Product), Taiwan (One Town One Product), Malaysia (Satu Distrik Satu Industri), dan Kamboja (One Village One Product). Pada umumnya penerapan OVOP bertujuan untuk menyelesaikan berbagai permasalahan kesenjangan sosial dan ekonomi yang terjadi antara desa dan kota di negara-negara Asia.

Kelurahan Kauman merupakan lokasi sentral UMKM Amplang yang dianggap masyarakat menjadi produk khas dari daerah tersebut dan sudah berlangsung selama bertahun-tahun dan masih bertahan sampai saat ini karena merupakan kegiatan ekonomi utama mayoritas pelaku usahanya. Meskipun usaha tersebut telah berjalan cukup lama, kelayakan finansial usaha tersebut belum diketahui. Selain itu, juga perlu dilakukan strategi pengembangan usaha. Sampai saat ini sebagian besar dari UMKM tersebut masih memiliki beberapa kendala, salah satunya adalah pada aspek pemasaran. Strategi pemasaran yang dilakukan masih menggunakan metode konvensional, dimana metode ini dianggap sudah kurang sesuai pada era digital saat ini.

Berbagai masalah yang dihadapi oleh UMKM Ampang tersebut tentunya perlu diberikan sebuah solusi. Penelitian ini merupakan bentuk pengabdian peneliti kepada masyarakat dengan berperan aktif dalam memecahkan masalah sehingga diharapkan dapat mendukung percepatan pertumbuhan ekonomi, khususnya di Kabupaten Ketapang. Melalui analisis aspek kelayakan finansial akan diketahui kelayakan usaha tersebut sehingga para pelaku usaha dapat terhindar dari kerugian. Selain itu juga akan diberikan rekomendasi strategi yang bisa diterapkan oleh pemilik UMKM, berupa pengoptimalan kekuatan dan peluang, serta meminimalisir kelemahan dan ancaman berdasarkan kondisi usaha saat ini sehingga tujuan agar produk Amplang menjadi One Village One Product di Kabupaten Ketapang bisa tercapai.

Penelitian mengenai penilaian aspek finansial dan strategi pengembangan usaha pada produk Amplang UMKM di Kelurahan Kauman belum pernah dilakukan 
sebelumnya. Sehingga sampai saat belum diketahui tingkat kelayakan usaha serta kekuatan, kelemahan, peluang dan ancaman apa saja yang terdapat pada UMKM tersebut. Selain itu sampai saat ini belum ada satupun produk OVOP di Kabupaten Ketapang. Sehingga penelitian ini bisa dianggap sebagai penelitian yang akan menghasilkan produk OVOP pertama di Kabupaten Ketapang.

\section{MATERI DAN METODE}

\section{Usaha Mikro, Kecil dan Menengah (UMKM)}

Usaha mikro kecil dan menengah (UMKM), merupakan salah satu kekuatan pendorong terdepan dalam pembangunan ekonomi (Bank Dunia, 2005). UMKM memegang peranan yang sangat penting dalam perekonomian sebuah negara. Kontribusi termaksud terutama pada penyerapan tenaga kerja Pada tahun 2005, UMKM di Indonesia mampu menyerap $77.678,498$ ribu orang atau sebesar $96,77 \%$ dari total tenaga kerja yang mampu diserap oleh usaha skala kecil, menengah, dan besar (Susilo, 2007). Meskipun peran UMKM sangat signifikan namun masih banyak masalah yang dihadapi oleh UMKM, salah satunya mengenai rendahnya produktivitas. Rendahnya produktivitas tersebut berkaitan dengan beberapa aspek, yaitu rendahnya kualitas sumberdaya manusia, dan rendahnya kompetensi kewirausahaan.

\section{Analisis Finansial}

Analisis finansial adalah sebuah anlisis yang bertujuan untuk mengetahui perkiraan dalam hal pendanaan dan aliran kas, sehingga dapat diketahui layak atau tidaknya bisnis yang dijalankan. Adapun analisis finansial dalam penelitian ini adalah dengan menggunakan perhitungan laba usaha.

\section{Laba Bersih}

Laba bersih adalah laba yang diperoleh oleh suatu usaha mengurangi laba kotor dengan biaya-biaya lainnya diluar harga pokok penjualan. Dengan kata lain laba bersih mengukur jumlah laba akhir yang tersisa setelah semua biaya dibayarkan salam suatu periode. Perhitungan laba bersih menggunakan rumus sebagai berikut:

Laba bersih $=$ Laba Kotor - Biaya Operasional

\section{Analisis SWOT}

Analisis SWOT merupakan suatu alat analisis yang digunakan untuk mengambil suatu kebijakan yangdibuat berdasarkan kekuatan, kelemahan, peluang, dan ancaman yang dimiliki oleh sebuah perusahaan yang berasal dari faktor internal dan eksternal. Data yang berasal dari analisis faktor internal dan eksternal tersebut kemudian akan digunakan untuk menentukan posisi pengembangan suatu usaha. Analisis faktor internal dilakukan untuk mengetahui kekuatan perusahaan yang dapat dimanfaatkan dan kelemahan yang harus diatasi. Sedangkan analisis faktor eksternal dilakukan untuk melihat peluang dan ancaman terhadap usaha. Pengembangan usaha yang akan dilakukan disesuaikan dengan posisi perusahaan dalam matriks SWOT. Matriks SWOT dapat dibagi menjadi empat jenis strategi yaituStrengths-Opportunity (SO), WeaknessOpportunity (WO), Strengths-Threats (ST) dan Weakness-Threats (WT).

\section{Prinsip Dasar Pendekatan OVOP}

Munculnya OVOP dilatarbelakangi oleh tiga hal yaitu: pertama, kepadatan populasi yang terkonsentrasi di perkotaan sebagai akibat urbanisasi sehingga populasi penduduk di pedesaan mengalami penurunan. Kedua, pemanfaatan potensi dan kemampuan daerah tersebut serta melibatkan para tokoh masyarakat setempat, untuk membangkitkan pertumbuhan ekonomi di pedesaan melalui suatu roda kegiatan ekonomi yang sesuai dengan skala dan ukuran pedesaan dengan cara. Ketiga, mengurangi ketergantungan masyarakat desa yang terlalu tinggi terhadap pemerintah daerah maupun pemerintah pusat. Lebih lanjut, agar OVOP dapat diimplementasikan, ada tiga prinsip OVOP yang harus dipahami, yaitu: lokal tapi global, kemandirian dan kreativitas, dan pengembangan sumberdaya manusia.

\section{Produksi Lokal di Pasar Global (Local Yet Global)}

Prinsip lokal tapi global merupakan upaya pemanfaatan potensi sumber daya lokal daerah untuk menghasilkan produk tertentu yang menjadi kebanggaan masyarakat setempat yang mampu mencapai skala global. Setiap daerah menggali potensi sumber daya dan memacu menghasilkan produk yang spesifik/unik, perpaduan antara potensi, kearifan dan budaya lokal yang memiliki nilai tambah tinggi, kesesuaian dengan standar pasar internasional, dan tetap menjaga kelestarian lingkungan. 
Sehingga produk OVOP dapat dipasarkan secara internasional, namun tetap disukai di pasar lokal.

\section{Kemandirian dan Kreativitas (Self Reliance and Creativity)}

Kegiatan usaha akan dilakukan dengan mengandalkan kemampuan masyarakat. Artinya usaha dilaksanakan secara mandiri dengan inovasi dan kreativitas, ketekunan, dan potensi sumber daya, serta pengetahuan masyarakat itu sendiri. Pada akhirnya, masyarakat akan memilih dan menentukan menentukan produk yang ingin dikembangkan karena dirasa memiliki kekhasan/keunikan lokal. Pemerintah memberikandukungan dan fasilitasi serta kemudahan agar potensi yang ada menjadi lebih baik, termasuk advokasi teknis, mediasi, pedoman teknis cara berproduksi yang baik, mengembangkan produk agar lebih menarik, menerapkan teknologi dan metoda baru, standardisasi, serta informasi investasi dan akses pemasaran (Pasaribu, 2011).

\section{Berorientasi Sumber Daya Manusia (Human Resource Development)}

Tujuan pengembangan SDM adalah agar masyarakat mempunyai motivasi tinggi untuk mengubah tantangan menjadi peluang. SDM yang mapan tidak akan pernah menyerah dalam pencarian dan penggalian inovasi baru, serta dengan ketekunannya tidak pernah putus asa karena kegagalan, dan dengan resiliensi yang dimiliki selalu siap menghadapi tantangan. Dengan prinsip diatas, maka pendekatan OVOP adalah suatu pendekatan pengembangan daerah secara terintegrasi yang dengan gerakan bersama menghasilkan satu produk berkelas global yang unik/khas daerah dan dengan kearifan lokal memanfaatkan ketersediaan sumber daya yang tersedia (Pasaribu, 2011).

\section{Metode Penelitian}

\section{Lokasi dan Waktu Penelitian}

Penelitian dilaksanakan di UMKM Amplang yang terdapat di Kelurahan Kauman Kabupaten Ketapang. Adapun waktu penelitian dilakukan selama tiga bulan yaitu pada bulan Juli September 2019.

\section{Teknik Pengambilan Sampel}

Teknik pengambilan sampel desa menggunakan metode purposive, dengan pertimbangan keterbatasan biaya, waktu dan tenaga yang disebabkan jangkauan wilayah yang luas dan kemudahan akses untuk seluruh desa rendah (Juanda, 2009).Responden dalam penelitian ini adalah pelaku UMKM yang memproduksi amplang di Kelurahan Kauman, Kabupaten Ketapang.

\section{Jenis dan Sumber Data}

Data yang digunakan dalam penelitian ini berupa data primer dan data sekunder. Data primer merupakan data hasil wawancara kepada responden terkait kondisi usaha meliputi kelemahan, kekuatan, ancaman dan peluang usaha. Sedangkan data sekunder merupakan data yang diperoleh dari literatur dan instansi terkait. Pengumpulan data primer pada penelitian ini dilakukan dengan teknik wawancara mendalam, dimana peneliti melakukan dialog langsungdengan responden untuk menggali informasi yang dibutuhkan dari responden. Selanjutnya pengumpulan data sekunder akan dilakukan melalui studi literatur yang dianggap sesuai dengan tujuan penelitian baik yang berasal dari instansi terkait maupun internet.

\section{Analisis Data}

\section{Analisis Finansial}

Metode analisis yang digunakan untuk mengetahui kondisi finansial usaha Amplang di Kelurahan Kauman Kabupaten Ketapang yaitu metode analisis finansial yang terdiri dari analisis harga pokok penjualan (HPP), laba bersih,Rate of Return (Jusup 2005) dan Break Event Point. Dalam penelitian ini hanya digunakan satu indikator yaitu laba bersih, dengan pertimbangan ketidakcukupan data untuk melakukan analisis finansial lainnya.

\section{Atribut pada tiap faktor}

Kekuatan: lokasi usaha, modal usaha pribadi, dan pengalaman; Kelemahan: manajemen usaha, manajemen pembukuan, dan pemasaran produk; Peluang: ketersediaan pasokan bahan baku, permintaan pasar, loyalitas pelanggan, media pemasaran; Ancaman: harga bahan baku, persaingan usaha dan keamanan pasar.

\section{Skor pada tiap atribut:}

Skor dalam kuesioner penelitian dengan menggunakan skala likert dengan rincian sebagai berikut:a. Skor kekuatan dan peluang: $1=$ tidak baik; 2 = kurang baik; 3 = cukup baik; 4 = baik; 5 
= sangat baik; $\mathrm{b}$. Skor kelemahan dan ancaman: 1 = sangat tidak berat; 2 = tidak berat; $3=$ cukup berat; 4 = berat; 5 = sangat berat.

Skor awal tiap atribut dikalikan dengan bobot kemudian akan dilakukan perhitungan faktor internal dan faktor eksternal dengan persamaan berikut:

Faktor internal = kekuatan - kelemahan Gambar 1. Diangram SWOT

\section{Faktor eksternal = peluang - ancaman}

Nilai faktor internal dan nilai faktor eksternal yang didapat selanjutnya diplotkan pada diagram SWOT. Terdapat empat kuadran dalam diagram analisis SWOT yang digunakan untuk mengidentifikasi strategi-strategi yang akan diambil.

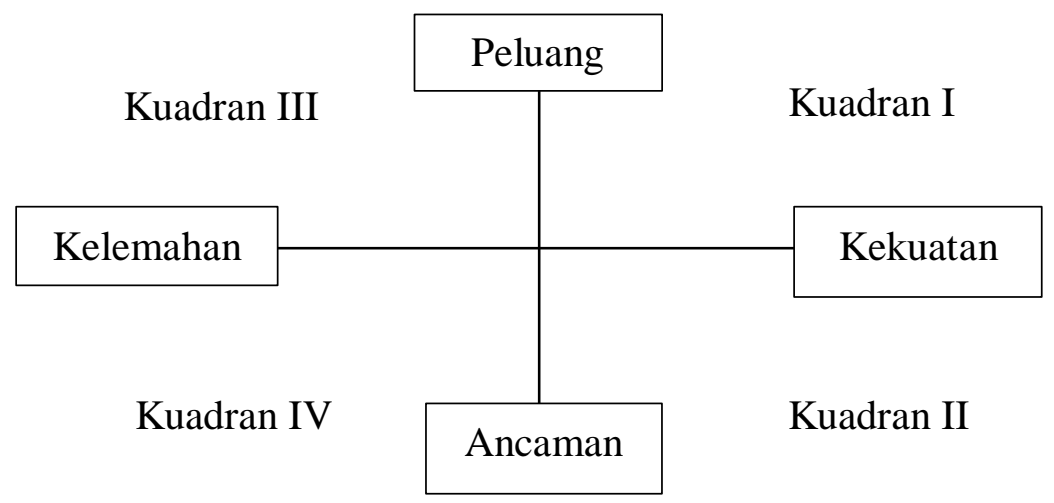

Adapun arti dari masing-masing kuadran pada diagram SWOT Gambar 5.1 (Rangkuti 2006; Muhammad 2008):

Kuadran I, posisi ini menunjukkan suatu usaha yang menguntungkan. Strategi yang diterapkan adalah agresif, sesuai dengan kekuatan usaha yang dimiliki dan besarnya peluang yang masih tersedia.

Kuadran II, posisi ini menunjukkan sebuah usaha yang kuat namun menghadapi tantangan yang besar. Strategi yang diterapkan adalah diversifikasi, melakukan sesuatu yang baru dengan keunggulan yang dimiliki untuk memasuki pasar baru dengan produk baru atau lama.

Kuadran III, posisi ini menandakan usaha yang lemah namun sangat berpeluang. Sebuah usaha tersebut harus dapat memanfaatkan peluang dengan mempertahankan penguasaan pasar yang dimiliki untuk meminimalkan kelemahan.

Kuadran IV, posisi ini menunjukkan usaha berada pada kondisi yang merugikan. Usaha harus memperbaiki strategi atau bahkan berhenti. Strategi penyelamatan sangat dibutuhkan untuk keberlangsungan usaha.

\section{HASIL DAN PEMBAHASAN}

\section{Hasil}

\section{Analisis Finansial}

Analisis finansial dilakukan dengan menghitung laba bersih dari setiap UMKM per satu bulan. Adapun hasil analisis dapat dilihat pada tabel dibawah:

Tabel 1. Data Pendapat UMKM Amplang

\begin{tabular}{|c|c|c|c|c|c|c|c|c|c|}
\hline & Sika Rasa & Faiz & Sari Rasa & $\begin{array}{c}\text { Amplang } \\
\text { Along }\end{array}$ & FN & Sari Belidak & OBIC & Citra Rasa & $\begin{array}{l}\text { Usaha } \\
\text { Baru }\end{array}$ \\
\hline $\begin{array}{l}\text { Total } \\
\text { biaya } \\
\text { variabl } \\
\text { e } \\
\end{array}$ & 29.243 .000 & 5.470 .000 & 9.365 .000 & 9.900 .000 & 4.410 .000 & 43.460 .000 & 67.510 .000 & 12.850 .000 & $\begin{array}{c}11.850 .00 \\
0\end{array}$ \\
\hline Harga/ & 140.000 & 140.000 & 150.000 & 140.000 & 140.000 & 140.000 & 140.000 & 140.000 & 140.000 \\
\hline
\end{tabular}


Volume 11 Nomor 2, Oktober 2020

\begin{tabular}{|l|c|c|c|c|c|c|c|c|c|}
\hline kg & & & & & & & & & \\
\hline $\begin{array}{l}\text { Biaya } \\
\text { Total }\end{array}$ & 38.243 .000 & 9.787 .000 & 15.215 .000 & 14.050 .000 & 8.210 .000 & 61.960 .000 & 90.510 .000 & 17.500 .000 & $\begin{array}{c}16.000 .00 \\
0\end{array}$ \\
\hline $\begin{array}{l}\text { Pendap } \\
\text { atan }\end{array}$ & 77.000 .000 & 15.400 .000 & 22.500 .000 & 18.200 .000 & 14.000 .000 & 112.000 .000 & 168.000 .000 & 21.000 .000 & $\begin{array}{c}21.000 .00 \\
0\end{array}$ \\
\hline Laba & 38.757 .000 & 5.613 .000 & 7.285 .000 & 4.150 .000 & 5.790 .000 & 50.040 .000 & 77.490 .000 & 3.500 .000 & 5.000 .000 \\
\hline
\end{tabular}

Berdasarkan tabel diatas diketahui bahwa tidak ada UMKM Amplang yang mengalami kerugian finansial dalam melakukan kegiatan usahanya. Seluruh UMKM mendapatkan keuntungan Rp.3.500.000 sampai dengan yang terbesar $\mathrm{Rp}$. 50.040.000. Pendapatan terbesar berasal dari UMKM Amplang OBIC, karena OBIC sudah melakukan perluasan pemasaran di luar daerah Kota Ketapang. Sehingga pendapatan yang diterima lebih besar dari UMKM lainnya. Namun secara keseluruhan dapat disimpulkan bahwa usaha Amplang layak untuk terus dijalankan karena memberikan keuntungan bagi para pelaku usahanya.

\section{Analisis SWOT}

Pada dasarnya setiap perusahaan perlu mengenali kekuatan dan kelemahan perusahaan dalam menghadapi persaingan. Sehingga perusahaan akan mampu mengenali diri, serta memanfaatkan setiap peluang yang ada dan menghindari atau meminimalkan setiap ancaman. Dalam proses menentukan strategi bersaing dan mengambil keputusan, seorang pemilik usaha harus mengenali apa saja kelemahan, kekuatan, ancaman, peluang yang dimiliki perusahaan serta mengenali berbagai keunggulan yang dimiliki pesaing.

Proses pengambilan kebijakan dalam suatu usaha yang paling umum dilakukan adalah melalui analisis SWOT. Analisis SWOT adalah suatu alat analisis yang dibuat berdasarkan kekuatan, kelemahan, peluang, dan ancaman yang dimiliki oleh sebuah perusahaan yang berasal dari faktor internal dan eksternal. Pada penelitian ini, uraian mengenai indikator kekuatan, kelemahan, peluang dan ancama usaha dapat dilihat pada tabel berikut:

Tabel 2. Indikator Faktor Internal

\begin{tabular}{lll}
\hline No & $\begin{array}{l}\text { Kekuatan } \\
\text { (Strength) }\end{array}$ & $\begin{array}{l}\text { Kelemahan } \\
\text { (Weakness) }\end{array}$ \\
\hline 1 & Lokasi usaha & Manajemen usaha \\
2 & Kualitas produk & $\begin{array}{l}\text { Manajemen } \\
\text { pembukuan }\end{array}$ \\
& & Pemasaran produk \\
\hline
\end{tabular}

Tabel 3. Indikator Faktor Eksternal

\begin{tabular}{lll}
\hline No & $\begin{array}{l}\text { Peluang } \\
\text { (Opportunity) }\end{array}$ & $\begin{array}{l}\text { Ancaman } \\
\text { (Threat) }\end{array}$ \\
\hline 1 & $\begin{array}{l}\text { Ketersediaan } \\
\text { pasokan bahan } \\
\text { baku }\end{array}$ & $\begin{array}{l}\text { Harga bahu } \\
\text { baku }\end{array}$ \\
2 & Loyalitas & Persaingan \\
& pelanggan & usaha \\
3 & Media & Keamanan \\
& pemasaran & pasar \\
\hline
\end{tabular}

Adapun hasil perhitungan dari faktor internal dan eksternal di atas adalah sebagai berikut

Tabel 4. hasil perhitungan faktor internal dan eksternal.

\begin{tabular}{|l|l|l|l|l|l|l|l|l|l|}
\hline & $\begin{array}{l}\text { Sika } \\
\text { Rasa }\end{array}$ & Faiz & $\begin{array}{l}\text { Sari } \\
\text { Rasa }\end{array}$ & $\begin{array}{l}\text { Amplang } \\
\text { Along }\end{array}$ & FN & $\begin{array}{l}\text { Sari } \\
\text { Belidak }\end{array}$ & OBIC & $\begin{array}{l}\text { Citra } \\
\text { Rasa }\end{array}$ & $\begin{array}{l}\text { Usaha } \\
\text { Baru }\end{array}$ \\
\hline S-W & 0,85 & 1,30 & 2,35 & 2,45 & 2,25 & 1,80 & 2,25 & 1,60 & 2,05 \\
\hline O-T & 1,30 & 1,00 & 1,125 & 1,45 & 1,60 & 1,45 & 1,65 & 1,40 & 1,55 \\
\hline
\end{tabular}

Penentuan bobot dan peringkat dalam tabel faktor Internal meliputi kekuatan dan kelemahan tersebut dilakukan oleh informan yang merupakan pemilik usaha melalui proses wawancara. Kemudian dianalisa oleh penulis sesuai dengan kondisi UMKM. Penentuan skor bobot dilakukan dengan cara mengkalikan bobot tiap indikator dengan peringkat tiap indikator kemudian menjumlahkan tiap indikator dari faktor kekuatan dan kelemahan dan menghitung selisih antara kedua faktor tersebut. Berdasarkan hasil perhitungan tersebut yang tersaji pada tabel diatas, selisih antara faktor kekuatan (strength) dan kelemahan (Weakness) seluruhnya bernilai positif, yang artinya bahwa nilai untuk kekuatan setiap.

Selanjutnya faktor peluang dan ancaman dilakukan proses perhitungan yang sama dengan 
faktor kekuatan dan kelemahan. Nilai pada faktor eksternal juga memiliki nilai yang positif, yang artinya nilai peluang yang dimiliki lebih besar daripada ancaman yang dihadapi.

Berdasarkan hasil perhitungan pada tabel di atas, seluruh UMKM bernilai positif yang berarti berada pada Kuadran I. Posisi ini menunjukkan suatu usaha yang menguntungkan, sehingga trategi yang diterapkan adalah agresif sesuai dengan kekuatan usaha yang dimiliki dan besarnya peluang yang masih tersedia.

\section{Pembahasan}

Berdasarkan hasil perhitungan dari tabel Faktor Internal dan Eksternal di atas maka UMKM Amplang dapat merumuskan formulasi strategi dengan menggunakan matriks SWOT yang dikembangkan oleh Weihrich (Wheelen dan Hunger, 2004:115 dalam Solihin, 2012:169). Matriks SWOT merupakan salah satu cara untuk mendapatkan alternatif strategi dengan cara menggabungkan masing-masing faktor yakni strategi SO (Strengths-Opportunities), strategi WO (Weaknesses-Opportunities), strategi ST (StrengthsThreats), dan strategi WT (Weaknesses-Threats).

Dari hasil penelitian, strategi dari matriks SWOT untuk UMKM Amplang ini yakni:

\section{Strategi So}

Strategi SO adalah strategi yang dihasilkan dari suatu cara pandang bahwa perusahaan atau unit bisnis tertentu dapat menggunakan kekuatan (strengths) yang mereka miliki guna memanfaatkan berbagai peluang (opportunities) (Solihin, 2012). Strategi SO untuk UMKM Amplang terdiri dari:

Lokasi usaha yang strategis. Lokasi UMKM yang berada di pusat kota mempermudah kegiatan produksi dan sangat mudah dijangkau oleh konsumen.

Mempertahankan kualitas produk. Bahan baku yang digunakan oleh UMKM Amplang menggunakan ikan segar sehingga akan berpengaruh pada cita rasa dan kualita Amplang.

Pengalaman usaha. Rata-rata usia UMKM Amplang adalah diatas 5 tahun, sehingga memiliki pengalaman dalam usaha yang cukup mumpuni.

Memanfaatkan kemajuan teknologidengan online marketing untuk memasarkan produk dengan membuat akun media sosial atau website merupakan strategi yang bisa dimanfaatkan oleh UMKM Amplang untuk memperbanyak jumlah pembelian produk dengan memanfaatkan peluang yang berupa tren yang ada di masyarakat kini yaitu online marketing

\section{Strategi ST}

Menurut Solihin(2012), strategi ST yaitu berbagai strategi yang dihasilkan dari suatu cara pandang bahwa perusahaan atau unit bisnis tertentu dengan menggunakan kekuatan (strengths) yang mereka miliki guna menghindari berbagai ancaman (threats). Adapun Strategi ST bagi UMKM Amplang terdiri dari: Menjaga kestabilan harga bahan baku, sehingga produk tidak mengalami kenaikan harga yang tinggi; Menjaga kualitas serta meningkatkan inovasi produk agar memiliki ciri khas yang unik dan berbeda diantara UMKM Amplang lainnya karena tingginya persaingan usaha.

\section{Strategi WO}

Strategi WO yaitu berbagai strategi yang dihasilkan dari suatu cara pandang bahwa perusahaan atau unit bisnis tertentu dapat memanfaatkan berbagai peluang yang ada di lingkungan eksternal dengan cara mengatasi segala kelemahan (weaknesses) sumber daya internal yang dimiliki oleh perusahaan saat ini (Solihin, 2012). Adapun Strategi WO untuk UMKM Amplang terdiri dari: Mempertahankan loyalitas konsumen terhadap produk dengan meningkatkan pelayanan; Memastikan ketersediaan bahan baku sehingga kegiatan produksi tetap bisa berjalan.

\section{Strategi WT}

Strategi WT yaitu berbagai strategi yang memang bersifat bertahan (defensive), serta bertujuan untuk meminimalisir semua kelemahan dan ancaman (Solihin, 2012). Adapun Strategi WT bagi UMKM Amplang terdiri dari: Memperbaiki manajemen usaha dan catatan pembukuan agar lebih terarah; Mempertahankan pemasaran produk yang sudah dilakukan saat ini; Berdasarkan hasil perhitungan pada tabel diatas, diketahui bahwa seluruh UMKM Amplang di Kelurahan Kauman berada pada kuadran I. Posisi ini membuktikan bahwa sebuah usaha yang kuat dan sangat berpeluang. Pada posisi ini, rekomendasi strategi yang bisa diberikan adalah strategi agresif, artinya perusahaan dalam kondisi yang menguntungkan. Sehingga benarbenar memungkinkan untuk terus menjalankan usaha, melakukan ekspansi, memperbesar pertumbuhan usaha serta mampu meraih kemajuan secara maksimal. Sehingga strategi yang paling tepat untuk dilakukan adalah strategi SO. 
Dari keempat strategi SO di atas, yang perlu dimaksimalkan adalah pada media pemasaran online. OBIC sebagai salah satu UMKM Amplang di kelurahan Kauman telah melakukan strategi ekspansi pasar agar usahanya semakin berkembang dan dikenal masyarakat. OBIC sudah mempeluas pemasaran produknya dengan membuka tempat produksi baru di Kota Pontianak. Adapun produk Amplang OBIC dipasarkan pada berbagai minimarket di kota Pontianak. Namun sayangnya sebagian besar UMKM Amplang lainnya belum melakukan strategi yang sama karena permasalahan utama UMKM adalah keterbatasan modal, sehingga untuk membuka sebuah cabang di kota baru akan dihadapkan dengan berbagai keterbatasan yang dimiliki UMKM.

Selain membuka cabang usaha baru, agar suatu perusahaan dapat memperbesar pertumbuhan usahanya, alternatif yang layak dicoba adalah dengan menggunakan penjulan produk secara online. Penjualan secara online dinilai lebih murah biaya, serta mempertimbangkan perubahan gaya hidup masyarakat pada era digital seperti saat ini. Ekspansi gaya hidup masyarakat saat ini ikut berubah karena pengaruh dari perkembangan teknologi dunia tersebut, salah satu yang paling mencolok dari perkembangan teknologi tersebut adalah gadget dan kecenderungan beraktivitas di dunia maya seperti berbelanja secara online atau lebih sering disebut dengan belanja online. (Setiowati et al., 2012).

Saat ini konsumen di Indonesia lebih tertarik pada penggunaan media jual beli online. Hal ini tidak lepas dari salah satu kemudahan yang dimiliki dalam jual beli online salah satunya adalah adanya kemudahan dalam mencari informasi tentang produk, informasi ini didapat dari adanya review atau tanggapan yang telah diberikan oleh konsumen yang telah membeli produk tersebut. Review yang ada menjadi salah satu pemicu terjadinya penjualan (Auliyaa et.al, 2017). Dari sisi finansial, pemasaran online sangat menjanjikan untuk peningkatan laba usaha. Realita dilapangan menunjukan bahwa, kebanyakan UMKM di Indonesia, memiliki beberapa permasalahan yang sama, salah satunya adalah kurangnya pengetahuan tentang pemasaran, disebabkan oleh terbatasnya informasi yang dapat dijangkau oleh UMKM mengenai pasar. (Setiawati dan Widyartati, 2017).Sehingga, ketika melakukan penjualan online, maka setiap usaha harus mampu mempromosikan produknya kepada konsumen.
Promosi yang baik akan mempengaruhi keinginan konsumen untuk membeli sebuah produk. Hampir seluruh UMKM Amplang tidak melakukan kegiatan promosi. Penyebabnya adalah karena Amplang merupakan produk makanan ringan yang umum diketahui oleh masyarakat Kalimantan Barat. Namun, Amplang mungkin tidak terlalu dikenal oleh masyarakat Indonesia di daerah lain. Sehingga promosi akan sangat berguna sebagai kegiatan memperkenalkan produk Amplang, khususnya bagi masyarakat di luar wilayah Kalimantan Barat yang akan membeli Amplang secara online. Peggunaan internet sebagai sarana baru pemasaran bagi UMKM Amplang tentu saja merupakan hal yang baru bagi pemilik UMKM. Sehingga jika ingin tercapainya perluasan dan pertumbuhan usaha tersebut, maka perlu dilakukan pembinaan terhadap para pemilik usaha bagaimana melakukan pemasaran dengan media online.

Ketika para pemilik usaha sudah mampu melakukan kegiatan pemasaran secara online, maka diharapkan pemasaran produk Amplang akan menjadi sangat luas sehingga Amplang akan dikenal sebagai sebuah produk khas yang dimiliki oleh Kelurahan Kauman Kabupaten Ketapang. Hal ini sesuai dengan salah satu prinsip OVOP, yaitu prinsip lokal tapi global yang merupakan upaya pemanfaatan potensi sumber daya lokal daerah untuk menghasilkan produk tertentu yang menjadi kebanggaan masyarakat setempat yang mampu mencapai skala global. Amplang sudah memenuhi prinsip ini dengan menjadi salah satu produk ciri khas Kelurahan Kauman. Selanjutnya yang perlu diperhatikan adalah mencapai tahap global dengan memanfaatkan media online. Namun karena akan dipasarkan secara global, maka kualitas dari produk Amplang tentu harusmengikutikesesuaian dengan standar pasar internasional agar dapat diterima, namun tidak mengubah ciri khas dari Amplang itu sendiri. Dengan demikian Amplang yang menjadi produk OVOP dapat dipasarkan secara internasional, namun tetap disukai di pasar lokal.

\section{KESIMPULAN}

Produk UMKM Amplang memiliki omset yang cukup besar setiap bulannya, sehingga secara finansial dinyatakan layak untuk terus dilaksanakan. Selain itu berdasarkan hasil analisis SWOT dengan perhitungan selisih antara kekuatan dan kelemahan, serta peluang dan ancaman, seluruh UMKM amplang memiliki nilai 
positif yang artinya berada pada posisi kuat dan sangat berpeluang, sehingga strategi yang paling sesuai untuk UMKM Amplang adalah strategi SO dengan pengoptimalan pada pemasaran online. Melalui pemasaran online diharapkan bahwa produk Amplang dapat diterima oleh pasar global, namun tetap harus mempertahankan ciri khas produknya. Dengan demikian maka Amplang layak untuk menjadi produk OVOP.

\section{DAFTAR PUSTAKA}

Auliyaa, Zakky Fahma., Moh Rifqi Khairul Umamb dan Septi Kurnia Prastiwi. 2017. Online Costumer Reviews (OTRs) dan Rating: Kekuatan Baru pada Pemasaran Online di Indonesia. Jurnal EBBANK Vol.8 No.1. Pp 89-98.

Bank Dunia, 2005, "Mendukung Usaha Kecil dan Menengah", Policy Brief. Diakses dari http://www.worldbank.or.id

Juanda B. 2009. Metodologi Penelitian Ekonomi dan Sains. IPB Press. Bogor.

Muhammad S. 2008. Manajemen Strategik Kosep dan Kasus. UPP STIM YKPN. Yogyakarta.

Pasaribu, Sahat M. 2011. Forum Penelitian Agro Ekonomi. Pengembangan AgroIndustri Perdesaan Dengan Pendekatan One Village One Product (OVOP). Developing Agro-Industry in Rural Areas Using One Village One Product (OVOP) Approach. Volume 29 No. 1, Juli 2011 : 111.

Raliby, Oesman dan Retno Rusdjijati. 2016. Analisis Potensi Unggulan Daerah
Kabupaten Magelang Menuju One Vilage One Product. Seminar Nasional IENACO. hlm 769-777.

Rangkuti F. 2006. Analisis SWOT Teknik Membedah Kasus Bisnis. PT Ikrar Mandiriabadi. Jakarta.

Setiawati, Ira dan Penta Widyartati. Pengaruh Strategi Pemasaran Online Terhadap Peningkatan Laba UMKM. Seminar Nasional dan Call for Paper 2017 Strategi Pengembangan Sumber Daya Manusia Melalui Publikasi Jurnal Ilmiah dalam Menyikapi Permenristekdikti RI No.20 Tahun 2017. Pp.343-347

Setiowati Apriliani Kartika., Widayat dan Jasly By. 2012. Sikap Online Shopping Dan Niat Pencarian Informasi Terhadap Niat dan Perilaku Belanja.Jurnal Manajemen Bisnis. 2(1) pp: 3-8.

Solihin, Ismail. 2012. Manajemen Strategik. Jakarta: Penerbit Erlangga.

Sri Susilo, Y., 2007. Pertumbuhan Usaha Industri Kecil dan Menengah (IKM) dan Faktor-faktor yang Mempengaruhinya. Eksekutif, Volume 4, Nomor 2, Agustus $2007306-313$

Triharini, Meirina., Dwinita Larasati \& R. Susanto. 2014. Pendekatan One Village One Product (OVOP) untuk Mengembangkan Potensi Kerajinan Daerah Studi Kasus: Kerajinan Gerabah di Kecamatan Plered, Kabupaten Purwakarta. ITB J. Vis. Art \& Des, Vol. 6, No. 1; 29-42. 